\title{
Biomarkører er nyttige ved bløtvevssarkomer
}

\author{
Lavt uttrykk av immunceller i bløtvevssarkomer kan tyde på dårligere \\ prognose, også når svulsten kan fjernes kirurgisk med god margin.
}

Bløtvevssarkomer er en sjelden, men aggressiv krefttype som også kan ramme barn. Tradisjonelle risikofaktorer vil i liten grad kunne forutsi prognosen. Ved å identifisere biomarkører som tilsier dårlig prognose, kan pasientene gis ytterligere, spesifikk behandling.

I sin avhandling viser Sveinung Wergeland Sørbye hvordan immunceller og genuttrykk i vevsprøver fra 249 sarkompasienter ved hjelp av immunhistokjemi ble undersøkt og sammenholdt med kliniske data. Pasienter med lavt uttrykk av immunceller, som CD4- og CD8-positive T-celler, hadde kortere sykdomsspesifikk overlevelse. Spesielt pasienter med lavt uttrykk av CD20-positive B-celler kom dårlig ut. Det samme gjaldt sarkompasienter med høyt uttrykk av markøren Skp2 eller kombinert høyt uttrykk av markørene M-CSF og TGF-beta. Kvinner med kreftsvulster med høyt uttrykk av Skp2 har kort forventet levetid hvis de ikke får tilleggsbehandling. Særlig hos pasienter hvor man ellers ville forventet høy overlevelse, som der man hadde oppnådd adekvate kirurgiske marginer, var det sammenheng mellom lavt uttrykk av immunceller og dårlig prognose.

- På sikt kan disse biomarkørene være med på å styre behandlingen. Før biomarkører kan tas i bruk i klinisk praksis, må det gjennomføres prospektive randomiserte studier for å se om mer målrettet behandling kan bedre overlevelsen for høyrisikopasienter, sier Wergeland Sørbye.

\section{Sigurd Høye}

sigurd.hoye@legeforeningen.no

Tidsskriftet

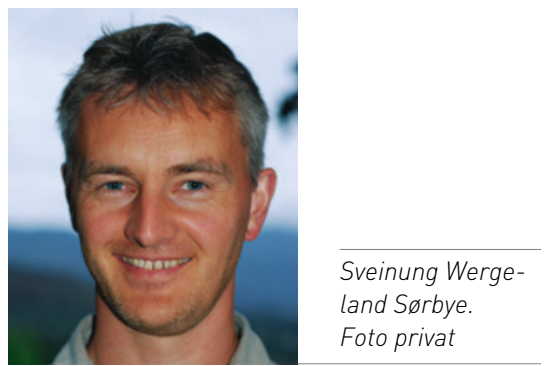

Disputas

Sveinung Wergeland Sørbye disputerte for ph.d.-graden ved Universitetet i Troms $\varnothing 26.9$. 2013. Tittelen på avhandlingen er Prognostic value of adaptive and innate immune systems in soft tissue sarcomas.

\section{Ultralyd ved langvarige fødsler}

\section{Ultralyd er et godt diagnostisk verktøy til å vurdere fødsler med langsom fremgang.}

De fleste fødsler forløper uten alvorlige problemer, men langsom fremgang er vanlig hos førstegangsfødende. Årsaker kan være dårlige rier, feilinnstilling, stort foster eller trangt bekken. Tradisjonelt vurderer fødselshjelpere fødselens fremgang med hendene, men dette er en subjektiv undersøkelse. Ultralydundersøkelse blir mye brukt i løpet av svangerskapet, men lite under selve fødselen. Bør ultralydapparatet flyttes inn på fødestuene?

I sitt doktorgradsprosjekt har Erik Andreas Torkildsen undersøkt 110 førstegangsfødende med langsom fremgang i første stadium. Hovedeffektmål var vaginal fødsel versus keisersnitt. Fosterhodets nivå og posisjon i fødselskanalen ble undersøkt med ultralyd. Dette ble sammenliknet med tradisjonell klinisk undersøkelse. Det ble brukt to målemetoder for nivå: avstanden fra fosterhodet til perineum (avstandsmetoden) og vinkelen mellom fosterhodet og symfysen (vinkelmetoden). Dessuten ble det anvendt både toog tredimensjonal ultralydteknikk.

Hvis fødselen stoppet opp når hodet lå høyt i fødselskanalen, var det stor risiko for keisersnitt, men dersom hodet hadde passert midtre del av kanalen, fødte $90 \%$ av kvinnene vaginalt. Fosterhodets posisjon i bekkenet hadde liten betydning for det videre fødselsforløpet, trolig fordi hodet vanligvis roterer spontant.

- Avstandsmetoden og vinkelmetoden samsvarte godt, og resultatene fra to- og tredimensjonal teknikk var likeverdige. Todimensjonal teknikk bør derfor foretrekkes fordi det er en enklere undersøkelse og utstyret er rimeligere, sier Erik Andreas Torkildsen.

- Ultralyd er en mer objektiv teknikk enn manuell undersøkelse og kan gjøre det lettere for fødselshjelperen å stille mer nøyaktige diagnoser. Undersøkelsen med ultralyd er rask og enkel og gir informasjon direkte på fødestuen. Dette vil kunne gjøre det enklere å vurdere det rette tidspunktet for eventuelt keisersnitt og unngå unødvendige keisersnitt, sier Torkildsen.

\section{Sigurd Høye}

sigurd.hoye@legeforeningen.no

Tidsskriftet

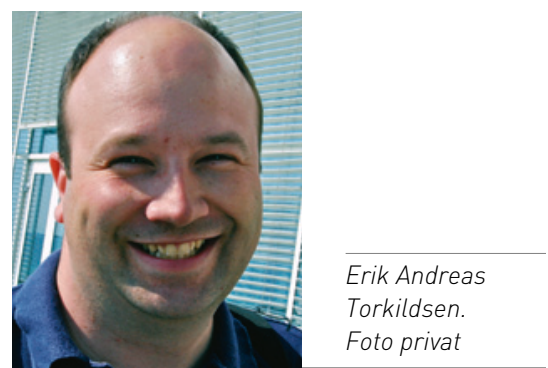

Disputas

Erik Andreas Torkildsen disputerte for ph.d.graden ved Norges teknisk-naturvitenskapelige universitet 20. 9. 2013. Tittelen på avhandlingen er Ultrasound \& prediction of prolonged labor 